Submitted $29^{\text {th }}$ Juni 2021

Accepted $15^{\text {th }}$ Agustus 2021

\title{
PELATIHAN VIDEOGRAFI PROMOSI SEDERHANA UNTUK PEMULA
}

\author{
Komang Trisna Pratiwi Arcana ${ }^{1}$, Komang Ratih Tunjungsari ${ }^{2}$, I Ketut Muliadiasa ${ }^{3}$ \\ Institut Pariwisata dan Bisnis Internasional, Denpasar \\ ratih.tunjung@ipb-intl.ac.id, trisna.pratiwi@ipb-intl.ac.id
}

\begin{abstract}
Desa Kuta merupakan salah satu desa yang saat ini terdampak pandemi karena salah satu destinasi wisata di Bali. Institut Pariwisata dan Bisnis Internasional merupakan kampus pariwisata dan perhotelan yang wajib melaksanakan tridarma perguruan tinggi, terdiri dari pengajaran, penelitian, serta pengabdian masyarakat. Kondisi perekonomian saat ini sangat berdampak kepada masyarakat di sekitar Kuta yang mata pencahariannya sebagian besar di bidang pariwisata. Kondisi pandemi seperti ini dapat dimanfaatkan untuk menambah keterampilan diri dalam berbagai hal positif, salah satunya adalah membuat video promosi, Video promosi dapat digunakan secara berkelanjutan untuk promosi dan menarik pelanggan baru ataupun mengingatkan pelanggan lama untuk dating kembali ke suatu bisnis. Pengumpulan data pada penelitian ini menggunakan metode observasi dan dokumentasi. Teknik analisis data yang digunakan adalah analisis exploratorI. Adapun strategi yang digunakan adalah mensinergikan kemampuan mahasiswa, dosen kampus IPB Internasional serta dosen kampus dari Institut Seni Indonesia Denpasar dan dosen dari STIKI Indonesia untuk memberikan pelatihan video promosi sederhana untuk pemula. Harapannya dengan dilakukannya kegiatan ini, masyarakat lokal menjadi lebih terampil dan dapat memanfaatkan keterampilannya tersebut untuk menambah penghasilan di masa pandemi ini.
\end{abstract}

Kata kunci: videografi, promosi, pemula

\section{PENDAHULUAN}

Wabah COVID-19 yang pertama kali dideteksi di kota Wuhan, China pada tanggal 31 Desember 2019 telah memicu dampak negatif bagi aktifitas masyarakat diseluruh dunia. Pandemi COVID-19 telah membuat roda perputaran ekonomi diseluruh negara berdenyut lemah, baik skala besar, menengah maupun kecil. International Monetary Fund ( IMF) telah menyatakan bahwa pertumbuhan ekonomi dunia menurun sebesar 0,1 - 0,2\% menjadi sebesar 3,3\% pada tahun 2020 (diakses dari www.kompas.com). Dampak lain yang ditimbulkan adalah banyaknya maskapai penerbangan yang menutup akses dari dan ke China seperti Amerika Serikat, Jerman, Indonesia, Korea Selatan dan Mesir yang mengakibatkan turunnya jumlah kunjungan oleh masyarakat China ke luar negeri (diakses dari http://puslit.dpr.go.id/). Adanya pembatasan kegiatan dan perjalanan yang dijadikan opsi oleh pemerintah dalam menekan jumlah populasi yang terpapar virus COVID-19 berdampak pada terjadinya penurunan yang signifikan terhadap jumlah kunjungan wisatawan. Selama tahun 2020 kunjungan wisman ke Bali sebanyak 1.050.505 kunjungan, turun 83,26 persen dibandingkan tahun 
2019. Kondisi ini tercatat sebagai kunjungan terendah selama sepuluh tahun terakhir (diakses dari https://bali.bps.go.id/). Akibat dari hal tersebut banyak industri pariwisata yang terpaksa tutup hingga mengistirahatkan beberapa karyawan selama fase pandemic karena tidak adanya wisatawan yang berkunjung. Salah satu destinasi wisata di Bali yang turut mengalami dampak negatif dari pandemi COVID-19 adalah Kuta. Kuta yang dulunya menjadi destinasi para wisatawan yang sangat ramai mendadak sepi akibat adanya penyebaran virus COVID-19. Sepinya wisatawan di Kuta tentunya membawa dampak besar pada perekonomian, khususnya di bidang pariwisata. Ketua Perhimpunan Hotel Restoran Indonesia (PHRI) di kabupaten Badung menyampaikan bahwa 60 hotel di Bali akan dijual para pemiliknya. Beliau berharap agar paar pengusaha jangan langsung putus asak arena pandemi ini karena menurutnya pariwisata akan eksis sepanjang masa (innews-com.cdc.ampproject.org).

Krisis ekonomi yang tercipta dari adanya pembatasan sosial tersebut membuat pemerintah menggagaskan kebijakan baru untuk hidup berdampingan dengan pandemi COVID-19 yang disebut dengan "New Normal", yaitu perubahan perilaku atau kebiasaan untuk tetap melakukan aktivitas seperti biasa namun dengan selalu menerapkan protokol Kesehatan di tengah pandemi. Aturan seperti memakai masker, membersihkan tangan dan menjaga jarak social diakui sebagai norma baru dan teknologi tanpa sentuhan atau contactless technology yang mana dianggap sebagai solusi untuk mengisolasi diri sambil terus menjalankan bisnis. Solusi ini dapat menggantikan menu sebenarnya dengan kode QR yang dapat dipindai melakukan check-in hotel tanpa kontak, kunci kamar dengan seluler, pembayaran tanpa sentuhan, dan pemesanan dalam aplikasi (Fipra, 2020).

Selain itu, sarana yang dapat digunakan untuk meningkatkan kunjungan wisatawan pasca pandemi adalah strategi pemasaran melalui digital marketing. Penggunaan digital marketing untuk meningkatkan tingkat kunjungan wisatawan dipandang efektif dalam menarik minat dan kesadaran wisatawan terhadap suatu usaha. Menurut Suhardi et all (2021) digital marketing mampu memperluas jangkauan pemasaran dengan biaya yang tidak begitu mahal. Untuk itu selama era New Normal kami ingin membantu pengelolaan digital marketing sebagai media promosi dari usaha- usaha tersebut. Hal ini mengingat adanya peningkatan jumlah pengguna internet dan media sosial selama beberapa tahun terakhir (Hooter, 2020).

Sudah sejak lama masyarakat Bali perekonomiannya sangat bergantung pada pariwisata. Bahkan, lebih dari 52 persen kontribusi pariwisata terhadap PDB Bali. Akibat pandemi, hotel-hotel kosong dan restoran sepi pengunjung. Kondisi ini berpengaruh terhadap perekonomian Bali. Sehingga untuk pertama kalinya dalam sejarah, pertumbuhan perekonomian Bali mengalami kontraksi yang paling dalam sampai mencapai 12 persen.

Maka dari itu, tercetuslah ide untuk menyelenggarakan sebuah acara pelatihan pembuatan video promosi untuk pemula dengan menggunakan telepon seluler. Acara ini diharapkan bisa membantu para pelaku usaha pariwisata dan perekonomian Bali, terutama di daerah Kuta dalam meningkatkan promosi usaha mereka di dunia digital atau sosial media. Serta, menambah wawasan dan kreativitas bagi para peserta yang mengikuti acara ini.

Media sosial saat ini telah menjadi trend dalam komunikasi pemasaran. Media sosial adalah sebuah media online, dengan para penggunanya bisa dengan mudah berpartisipasi, berbagi, dan menciptakan isi meliputi blog, jejaring sosial, wiki, forum dan dunia virtual. Blog, jejaring sosial, dan wiki merupakan bentuk media sosial yang paling umum digunakan oleh masyarakat di seluruh dunia. Media sosial sebagai "sebuah kelompok aplikasi berbasis internet yang membangun di atas dasar ideologi dan teknologi Web2.0, 
dan yang memungkinkan penciptaan dan pertukaran user-generated content" (Kaplan \& Haenlein, 2010).

Saat ini Instagram digunakan sebagai aplikasi berbagi foto yang menawarkan kemudahan menghasilkan foto, mengunggah, dan menampilkan, serta kemudahan mengakses. Pada umumnya user perusahaan pada Instagram adalah pengguna yang menggunakan fasilitas jenis akun bisnis/merek/organisasi. Berdasarkan identifikasi platform atau wadah dalam Instagram secara langsung, fasilitas yang dimaksud antara lain buku dan majalah, merek dan produk, perusahaan atau organisasi, bisnis lokal, musik, film, olahraga, profesi, televisi, hingga situs dan blog.

Instagram merupakan aplikasi online yang digunakan untuk berbagi dan berkomunikasi di dalamnya. Media sosial Instagram diciptakan sehingga para pemilik smartphone akan merasa bahwa kamera yang terpasang di telepon genggamnya tidak siasia karena Instagram mengedepankan visual berupa foto dan video kepada penggunanya untuk memudahkan dalam berkomunikasi secara tidak langsung (Salamoon dalam Ghufron, 2019). Instagram memiliki kelebihan dan kekurangan yaitu : (1) gratis, (2) Media utama yaitu foto dan video pendek berdurasi 1 menit, (3) Mudah untuk digunakan, dan kekurangan yaitu : (1) Persaingan dalam Instagram (2) Transaksi penjualan secara tidak langsung.

Instagram yang akan digunakan dalam perancangan yaitu akun bisnis instagram. Terdapat perbedaan penggunaan akun pribadi dan bisnis pada instagram yaitu : (1) Profil bisnis, (2) Insight atau wawasan, serta (3) promosi.

Berdasarkan penjajakan yang dilakukan pada tanggal 5 Februari 2021, berikut adalah masalah yang dihadapi oleh para masyarakat Desa Kuta:

Dampak pandemic menjadikan banyaknya anggota Sekeha Teruna-Teruni yang belum memiliki kegiatan karena masa pandemi.

Sumber Daya yang terbatas dari segi keterampilan dalam pembuatan video promosi sederhana.

Pentingnya promosi untuk tetap berjalan meskipun di masa pandemi

\section{METODE}

Sasaran pokok kegiatan ini adalah masyarakat lokal Desa Kuta. Dipilihnya masyarakat lokal ini didasari atas asumsi keinginan yang sangat tinggi dan adanya dorongan positif dari Kepala Desa Adat Kuta. Bertempat di Hotel Rama Beach, dengan alamat Jl. Jenggala J1. Wana Segara No.31, Tuban, Kuta, Kabupaten Badung, Bali 80361. Waktu pelatihan atau pelaksanaan kegiatan yang berupa pelatihan berlangsung selama 1 hari pada hari Kamis tanggal 15 Juli 2021. Peserta Pelatihan: 20 orang masyarakat Kuta berusia produktif. Memperhatikan hasil kegiatan pengabdian maka metode yang akan digunakan untuk mengatasi permasalahan dilakukan dengan metode melalui diskusi, pelatihan dan pendampingan yaitu pertemuan secara berkala antara pendamping dengan masyarakat lokal. Model pendekatan yang dilakukan meliputi: (1) Model Knowledge Transfer, (2) Business model Innovation. Adapun langkah-langkah operasional yang dilakukan dalam kegiatan pengabdian ini diantaranya: Pelatihan pengenalan pentignya social media. Pelatihan cara pembuatan video promosi 


\section{HASIL DAN PEMBAHASAN}

\section{PESERTA KEGIATAN}

Peserta kegiatan BRAVE 2021 ini yaitu:

Management IPB Internasional

Dosen-dosen IPB Internasional

Pegawai dan staff IPB Internasional

Mahasiswa IPB Internasional

Mahasiswa diluar IPB Internasional

Tamu undangan pemilik/staff hotel dan restoran di daerah Kuta

\section{BENTUK KEGIATAN}

Kegiatan dibuka dengan kata sambutan oleh Petinggi IPB Internasional. kemudian MC memperkenalkan kedua pembicara, yaitu Ayu Pamungkas dan Rai Pendet kepada para peserta. Sesi pertama membahas tentang cara mencari ide dan naskah sebelum membuat video oleh Ayu Pamungkas dan pada sesi kedua dijelaskan oleh Rai Pendet mengenai teknis yang baik dan benar dalam mengambil video. Setelah kedua pembicara memaparkan materi, dibuka sesi tanya-jawab oleh para peserta (sebanyak 8 pertanyaan).

Sesi berikutnya yaitu sesi demonstrasi oleh Rai Pendet, dimana beliau langsung mempraktekkan cara mengambil video dan dijelaskan oleh Ayu Pamungkas. Video pun diperlihatkan kepada para peserta. kegiatan dilanjutkan dengan speed quiz, diambil 5 pemenang yang mendapatkan total uang dalam bentuk Gopay sebanyak Rp 100.000,-.

Kegiatan BRAVE ditutup dengan penyerahan souvenir dan sertifikat untuk pembicara oleh ketua panitia. Pembagian link absensi para peserta dibagikan pada grup Whatsapp oleh panitia untuk mendapatkan sertifikat. Dikarenakan diberlakukannya PPKM, maka kegiatan BRAVE diadakan secara online (petinggi, tamu undangan, peserta, panitia) dan panitia yang di tempat secara offline dimaksimalkan menjadi 10 panitia di Restoran Hotel Rama Beach, Kuta.

Adapun yang ditambahkan ada ruangan tersebut adalah beberapa tanaman, beberapa rak buku untuk bisa digunakan sebagai tempat menaruh buku sumbangan. Kemudian untuk ruang kreatif juga ada beberapa yang ditambahkan untuk digunakan sebagai dekorasi, seperti meja dan kursi santai agar menimbulkan kesan nyaman.

Beberapa foto di bawah mengambarkan kamar yang belum di set-up dan kamar yang sudah di set-up pada saat pelatihan. Pada gambar di atas yang lebih digunakan adalah pola kamar untuk bulan madu. Sehingga dengan pola kamar tersebut menjadi lebih tertata dan menarik. Selain itu, pemuda mendapatkan kebutuhan untuk melakukan set up honeymoon. Dalam pelaksanaan kegiatan pengabdian ini, kegiatan yang dilaksanakan untuk pemecahan masalah dalam mengolah makanan di Desa Tonja, Denpasar ini dilakukan dengan pelatihan merangkai janur dan bunga kering serta bertukar ide dan pendapat dengan masyarakat lokal. Berikut susunan kegiatan yang akan dilakukan:Gambar 1. Peserta Secara Daring 


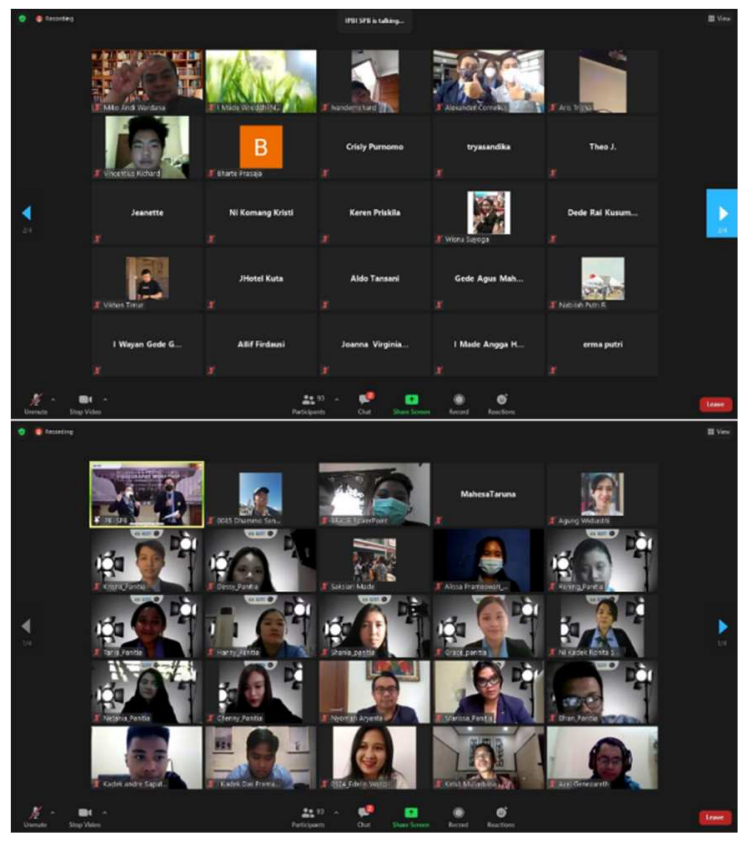

\section{Gambar 2. Foto Selama Kegiatan}

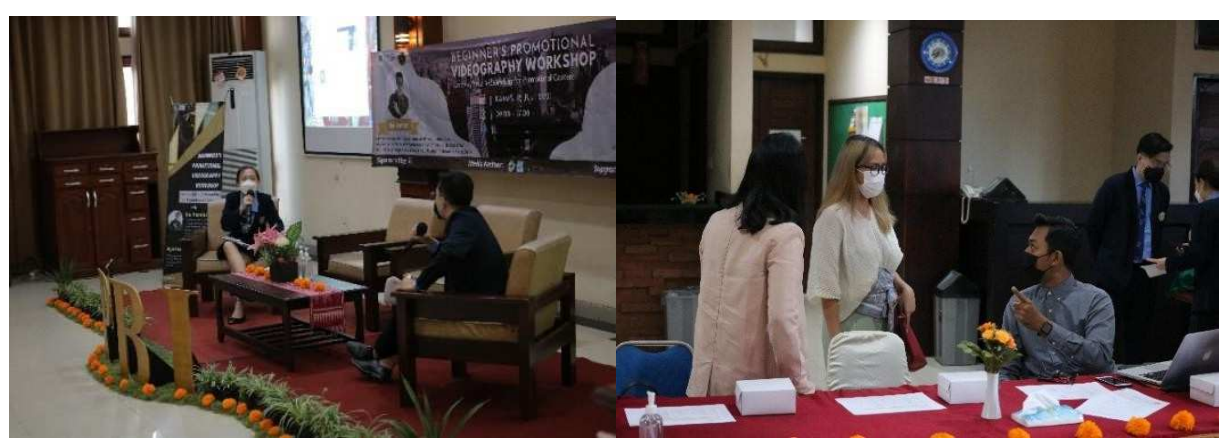

Gambar 3. Pembicara Menyampaikan Materi dan Panitia Memantau Kegiatan

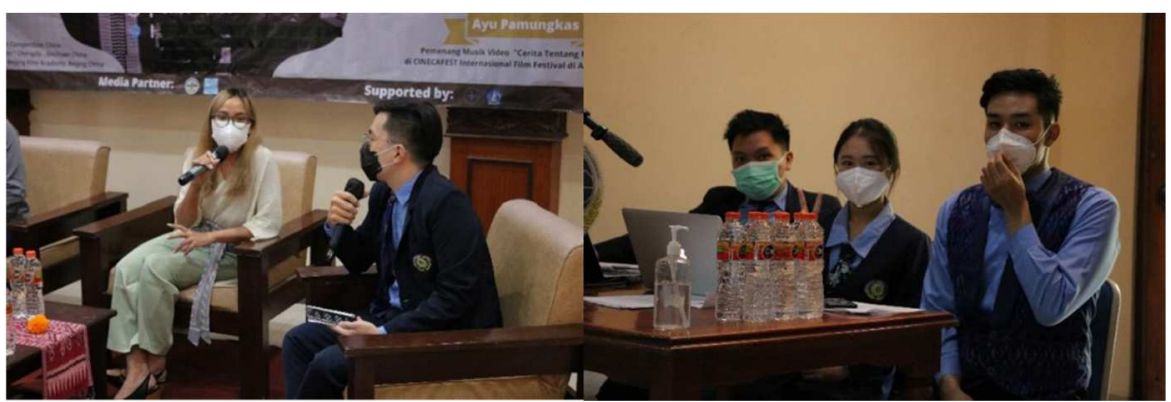


Gambar 4. Pembicara Sedang Praktek

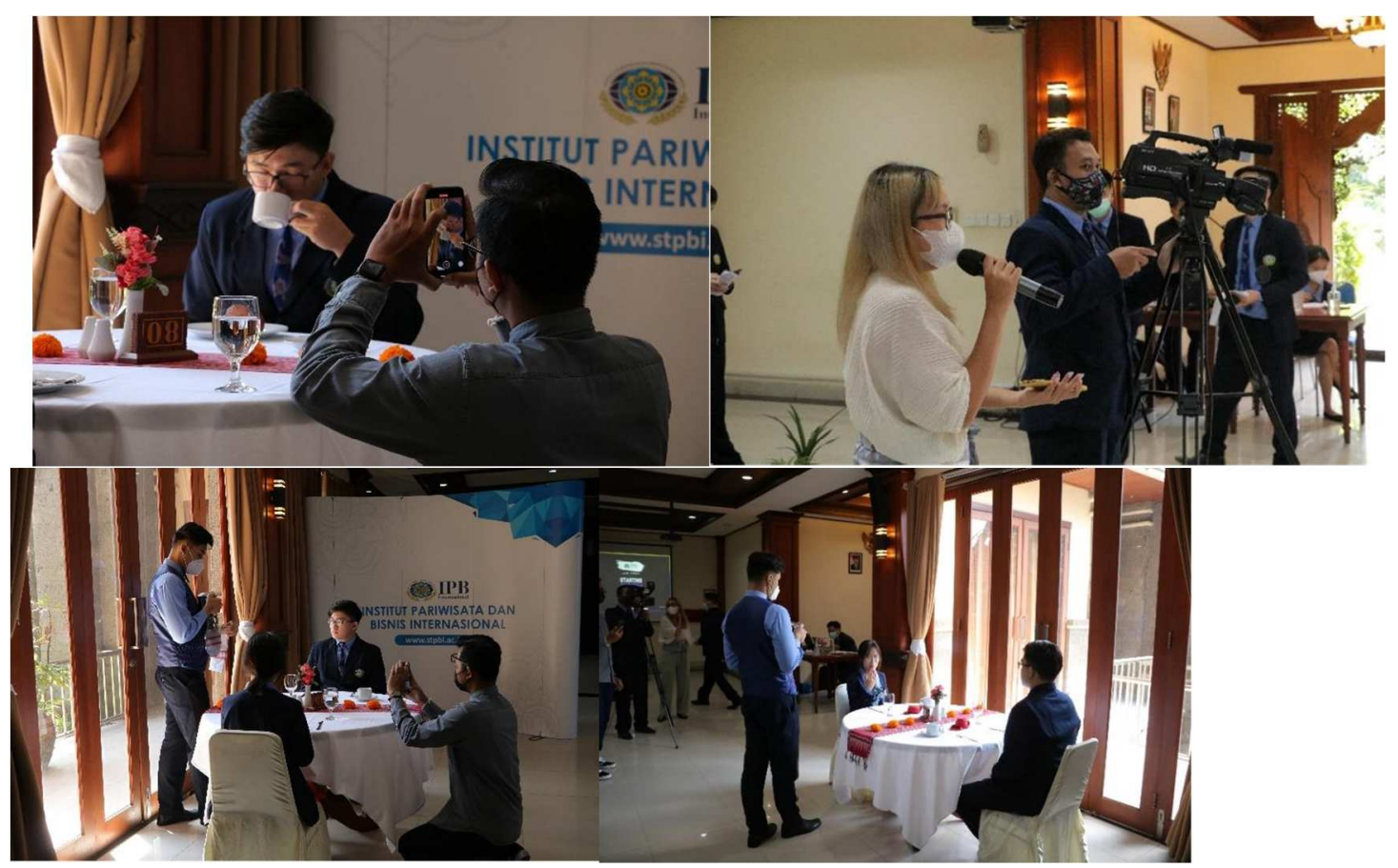

Gambar 5. Sesi Praktek oleh Panitia dan Pembicara

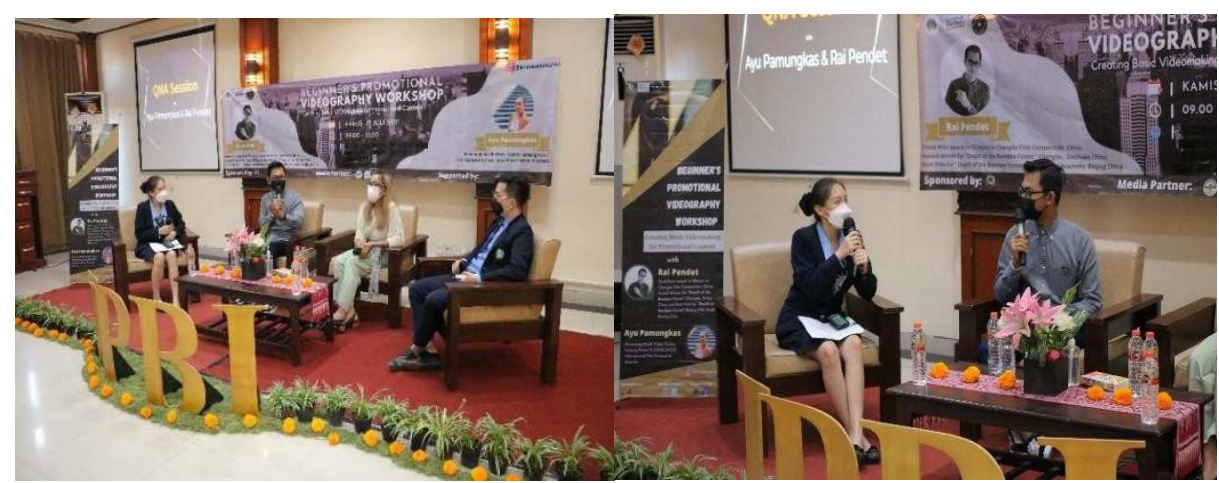

Gambar 6. Sesi Pembahasan

\begin{tabular}{|l|l|l|l|}
\hline $\begin{array}{c}\text { Februari- } \\
\text { Maret- } \\
\text { April }\end{array}$ & \multicolumn{1}{|c|}{ Tanggal } & \multicolumn{1}{|c|}{ Agenda Kegiatan } & \multicolumn{1}{|c|}{ Note } \\
\hline Week 1 & $\begin{array}{l}\text { 5 Februari } \\
2021\end{array}$ & $\begin{array}{l}\text { Mendiskusikan acara yang } \\
\text { akan dilakukan. }\end{array}$ & All \\
\hline Week 2 & 17 Februari & $\begin{array}{l}\text { Bimbingan dari dosen } \\
\text { pengampu mata kuliah } \\
\text { Event }\end{array}$ & $\begin{array}{l}\text { Dosen } \\
\text { pembimbing, } \\
\text { panitia inti }\end{array}$ \\
\hline Week 1 & 3 Maret & $\begin{array}{l}\text { Membuat Proposal } \\
\text { kegiatan }\end{array}$ & Wakil \\
\hline Week 3 & 19 Maret & Membuat Checklist & Wakil \\
\hline
\end{tabular}




\begin{tabular}{|l|l|l|l|}
\hline Week 4 & 25 April & $\begin{array}{l}\text { Pengecekan lokasi } \\
\text { kegiatan }\end{array}$ & All \\
\hline $\begin{array}{l}\text { Mei-Juni- } \\
\text { Juli }\end{array}$ & Tanggal & Agenda Kegiatan & Note \\
\hline Week 1 & 3 Mei 2021 & $\begin{array}{l}\text { Mendiskusikan detail } \\
\text { bahan seminar dengan } \\
\text { pembicara }\end{array}$ & $\begin{array}{l}\text { Panitia inti, dosen } \\
\text { pembimbing }\end{array}$ \\
\hline Week 2 & 15 Mei 2021 & Meeting panitia zoom & All \\
\hline Week 1 & 3 Juni 2021 & Meeting zoom & All \\
\hline Week 2 & 14, Juni 2021 & $\begin{array}{l}\text { Mendiskusikan dekorasi } \\
\text { tempat }\end{array}$ & Panitia inti \\
\hline Week 3 & 15, Juni 2021 & $\begin{array}{l}\text { Survei Konsumsi Peserta } \\
\text { \& Panitia }\end{array}$ & Sie Konsumsi \\
\hline Week 1 & 2 Juli 2021 & $\begin{array}{l}\text { Meeting dengan semua } \\
\text { panitia membahas tentang } \\
\text { progress kerja }\end{array}$ & $\begin{array}{l}\text { All, } \\
\text { pembimbing }\end{array}$ \\
\hline & 7 Juli 2021 & $\begin{array}{l}\text { Persiapan Tempat dan } \\
\text { Dekorasi }\end{array}$ & All \\
\hline Week 3 & 15 Juli 2021 & $\begin{array}{l}\text { Gradi kotor dan gladi } \\
\text { bersih }\end{array}$ & $\begin{array}{l}\text { Seluruh panitia \& } \\
\text { MC }\end{array}$ \\
\hline
\end{tabular}

Tabel 1. Susunan Kegiatan

Selain pelatihan pembuatan video promosi, pelatihan ini juga mengajarkan bagaimana membuat alur cerita yang baik dalam sebuah video. Sehingga video yang akan ditampilkan sesuai dengan apa yang ingin diiklankan. Pengabdian ini juga mengajarkan kepada masyarakat bagaimana dalam pengelolaan social media sebagai salah satu media untuk melakukan digital marketing. Mengingat semua kegiatan suatu institusi dapat dilihat dengan mudah melalui akun social media. Mengingat kebutuhan social media dan pembuktian di dunia maya saat ini sangatlah penting untuk kebutuhan pemasaran. 
Gambar 7. Sosial Media Kegiatan Pelatihan
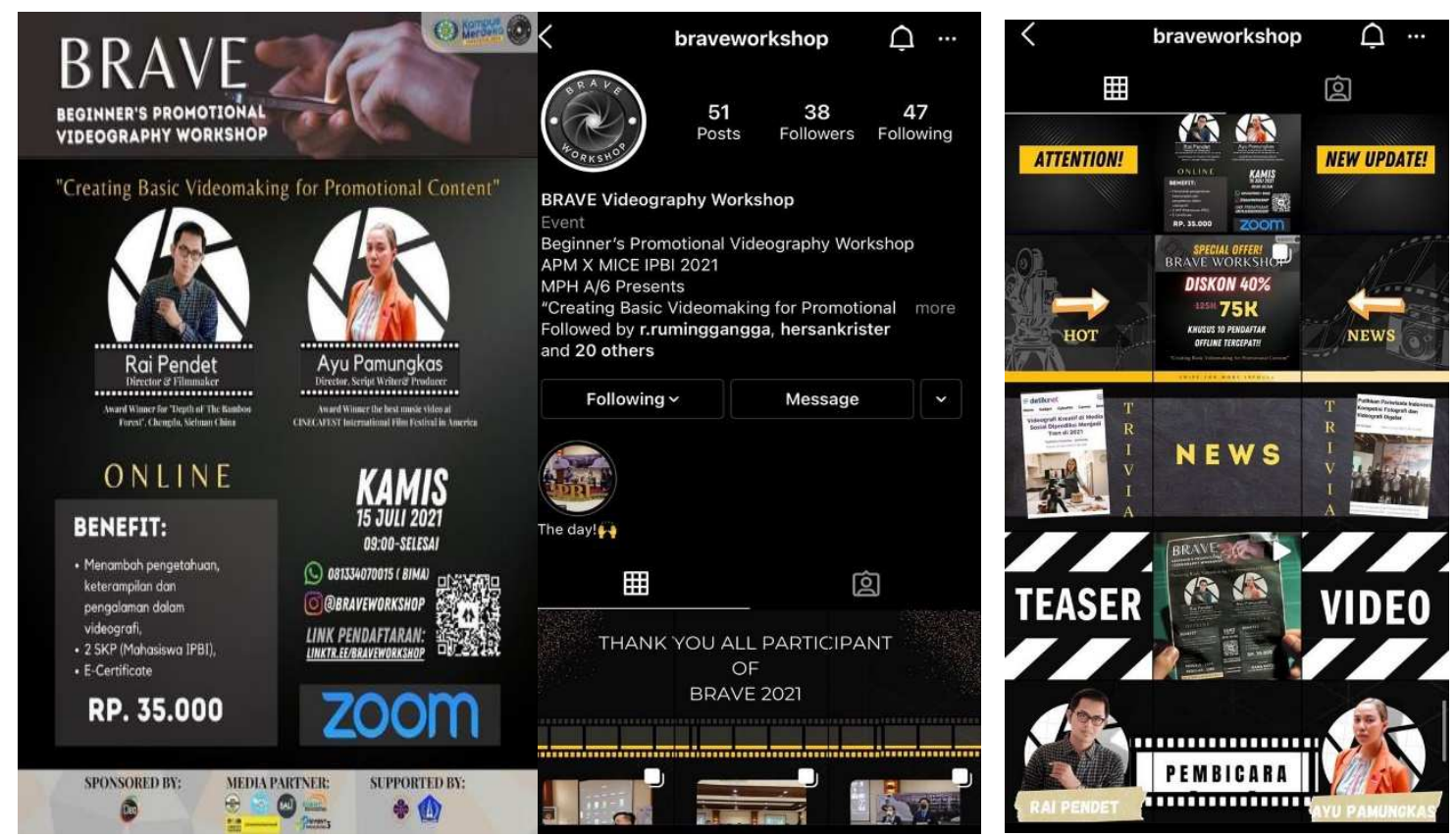

\section{EVALUASI PROGRAM PELATIHAN}

\begin{tabular}{|l|l|l|}
\hline NO & \multicolumn{1}{|c|}{ KENDALA } & PEMECAHAN MASALAH \\
\hline $\mathbf{1}$ & $\begin{array}{l}\text { DIVISI PERLENGKAPAN } \\
\text { Kebutuhan perlengkapan yang berubah- } \\
\text { ubah karena venue acara yang dirubah } \\
\text { karena ppkm darurat }\end{array}$ & $\begin{array}{l}\text { Banner yang sudah berisi lokasi } \\
\text { venue sebelumnya ditutupi dengan lakban } \\
\text { Penyewaan beberapa alat seperti HT } \\
\text { dan kamera dibatalkan dan digantikandengan } \\
\text { meminjam kamera dari } \\
\text { kampus }\end{array}$ \\
\hline $\mathbf{2}$ & $\begin{array}{l}\text { DIVISI PUBLIC RELATION } \\
\text { Saat pengiriman surat undangan untuk } \\
\text { hotel dan restaurant di daerah Kuta } \\
\text { banyak restaurant yang tutup karena } \\
\text { pandemi dan pengiriman surat } \\
\text { undangan menjadi tertunda }\end{array}$ & $\begin{array}{l}\text { Menghubungi terlebih dahulu Hotel dan } \\
\text { menanyakan apakah surat undangan dikirim } \\
\text { langsung atau melalui email atauWhatsapp }\end{array}$ \\
\hline $\mathbf{3}$ & $\begin{array}{l}\text { BENDAHARA } \\
\text { Tidak mengerti dan belum pernahdiajari } \\
\text { untuk membuat RAB dan Minimum } \\
\text { Selling Price }\end{array}$ & $\begin{array}{l}\text { Mencari materi dan tutorial pada internetdan } \\
\text { terus berkonsultasi dengan dosen pembimbing } \\
\text { hingga akhirnya RAB dan Minimum Selling } \\
\text { Price dapat dibuat } \\
\text { dengan baik }\end{array}$ \\
\hline $\mathbf{4}$ & $\begin{array}{l}\text { Didiskusikan bersama dan mencari bersama } \\
\text { kENDAHARA } \\
\text { Terdapat perbedaan pada penghitungan penghitungan yang dibuat hingga } \\
\text { oleh kedua bendahara }\end{array}$ \\
\hline $\begin{array}{l}\text { akhirnya ditemukan } \\
\text { dimana titik perhitungan yang salah atau } \\
\text { kurang dimasukkan }\end{array}$ \\
\hline
\end{tabular}




\begin{tabular}{|c|c|c|}
\hline 5 & $\begin{array}{l}\text { DIVISI ACARA } \\
\text { Awal pembentukan acara sedikit } \\
\text { kesulitan dalam menentukan nama dan } \\
\text { tema dari acara }\end{array}$ & $\begin{array}{l}\text { Melakukan rapat dan brainstorming bersama } \\
\text { anggota divisi acara, dan meminta vote dari } \\
\text { seluruh panitia melalui } \\
\text { Google Form }\end{array}$ \\
\hline 6 & $\begin{array}{l}\text { DIVISI ACARA } \\
\text { Selama persiapan acara, merasa adanya } \\
\text { ketidakadilan dalam pembagian tugas } \\
\text { oleh ketua dan wakil panitia }\end{array}$ & $\begin{array}{l}\text { Kepala divisi beserta anggota melakukan } \\
\text { musyawarah dengan ketua dan wakil panitia, } \\
\text { dan sepakat bahwa ada beberapa tugas yang } \\
\text { tidak seharusnya masuk ke } \\
\text { divisi acara }\end{array}$ \\
\hline 77 & $\begin{array}{l}\text { DIVISI ACARA } \\
\text { Kewalahan karena adanya perombakan } \\
\text { konsep dari acara lomba KUTTO } \\
\text { menjadi workshop BRAVE } \\
\text { harus meningga } \\
\text { secepatnya }\end{array}$ & $\begin{array}{l}\text { Melakukan rapat dan brainstorming bersama } \\
\text { ketua, wakil, serta anggota lainnya untuk } \\
\text { menyusun konsep baru berupa workshop } \\
\text { BRAVE }\end{array}$ \\
\hline 8 & $\begin{array}{l}\text { DIVISI ACARA } \\
\text { Kesulitan menentukan tanggal kosong } \\
\text { dengan kedua pembicara karena jadwal } \\
\text { mereka sempat bertentangan, sehingga } \\
\text { tanggal acara harus mundur } \\
\text { (cth: Kak Rai available tgl } 10 \text { Juni, Kak } \\
\text { Ayu berhalangan) }\end{array}$ & $\begin{array}{l}\text { Mengubah tanggal acara dan mengundur } \\
\text { pelaksanaan agar disesuaikan dengantanggal } \\
\text { available kedua pembicara setelah koordinasi } \\
\text { lebih lanjut }\end{array}$ \\
\hline 9 & $\begin{array}{l}\text { DIVISI SALES DAN MARKETING } \\
\text { Pencarian venue untuk pelaksanaan } \\
\text { workshop online dan offline. Dalam hal } \\
\text { ini, divisi sales and marketing perlu } \\
\text { mencari sponsor yang bersedia menjadi } \\
\text { lokasi BRAVE workshop }\end{array}$ & $\begin{array}{l}\text { Kami mendapatkan venue hotel Rama Beach } \\
\text { Hotel \& Resort yang bersedia untuk menjadi } \\
\text { venue dengan harga special untuk } 50 \mathrm{k} / \text { pax } \\
\text { untuk } 50 \text { orang }\end{array}$ \\
\hline
\end{tabular}

1. Faktor Pendukung Kegiatan

a. Kegiatan yang didukung penuh oleh pihak kampus

b. Peralatan dan teknologi yang memadai.

c. Kerjasama yang baik antara panitia dengan panitia dan panitia dengan dosen pengampu

d. Masing-masing panitia mampu memahami dan melaksanakan tugasnya.

e. Koordinasi antara panitia dengan perserta sangat baik sehingga acara berjalan dengan baik dan lancar.

2. Faktor penghambat kegiatan

Kendala pada sie perlengakapan.

Terjadinya miss komunikasi antara panitia dengan panitia

Solusi: dalam tim seharusnya lebih banyak komunikasi dan lebih kompak jika tidak ingin miss komunikasi dan seharusnya kita lebih menyimak dan mendengarkan apa yang di perintahkan oleh atasan

\section{Kendala pada sie dokumentasi.}

a. Panitia kurang paham menggunakan camera

Solusi: seharusnya sie dokumentasi harus paham tentang kamera minimal di pelajari sebelum hari $\mathrm{H}$ agar tidak adanya masalah dalam mengambil foto atau video

b. Kurangnya peserta untuk mendokumentasikan 
Solusi: seharusnya sie dokumentasi minimal 2 panita agar bisa mengambil video dan foto secara bersamaan dalam 1 moment.

\section{DAMPAK PROGRAM PELATIHAN}

Program pengabdian pelatihan dapat memberikan efek positif bagi masyarakat Desa Kuta untuk menambah ilmu di bagian social media, terutama untuk mengedit video dan menjadikannya video promosi. Selama ini masyarakat Desa Kuta belum memanfaatkan secara maksimal social media yang dimiliki. Sehingga dengan terlaksananya kegiatan pengabdian ini, diharapkan dapat memperkenalkan masyarakat Kuta serta para pekerja untuk dapat mengelola social media lebih baik melalui video promosi yang telah dipelajari.

\section{SIMPULAN}

Pengabdian Pelatihan Video Promosi Sederhana harus melakukan komunikasi yang baik antara masyarakat yang terdampak dengan COVID sehingga, memberikan salah satu pelatihan dapat meningkatkan keahlian dari masyarakat untuk dapat mengelola social media. Pembuatan video sederhana sangat dibutuhkan keahlian untuk dapat mengelola suatu akun social media oleh para pemasar di hotel, restaurant Kuta untuk dapat terus berkarya. Meskipun pandemi COVID namun kreatifitas untuk berkarya harus tetap berlangsung.

\section{UCAPAN TERIMAKASIH}

Puji syukur kehadirat Tuhan Yang Maha Esa, Sesuhunan yang melindungi civitas akademika IPB Internasional, sehingga kegiatan pengabdian dapat dilaksakanan sesuai dengan perencanaan serta mendapatkan respon dan berdampak baik terhadap semua pihak. Ucapan terima kasih disampaikan kepada Rektor IPB Internasional beserta seluruh jajarannya serta Ketua Yayasan Dharma Widya Ulangun yang menaungi kampus IPB Internasional. Ucapan terima kasih juga disampaikan kepada Ketua LPPM IPB internasional beserta sekretaris LPPM atas masukan serta saran sebelum dan selama pelaksaaan kegiatan pengabdian ini. Ucapan terima kasih juga disampaikan kepada seluruh elemen pendukung kegiatan ini, meliputi: mahasiswa Program Studi Diploma 4 Manajemen Pariwisata, Program Studi Diploma 4 Manajemen Perhotelan dan Program Studi Diploma 3 Perhotelan Kampus IPB Internasional.

\section{DAFTAR PUSTAKA}

Kaplan, A. M., \& Haenlein, M. (2010).

Users of the world, unite! The challenges and opportunities of Social Media. Business horizons, 53(1), 59-68.

Ghufron, N.A (2019). Perancangan Kontan Akun Bisnis Instagram Berbasis Fotografi : Studi Kasus Toko Kue Ayu. Jurnal Paper UISI. 